\title{
THE IMPACT OF DEVELOPMENTAL CRISES, THE SENSE OF MEANING IN LIFE AND IDENTITY EXPANSION ON CULTURAL TOURIST BEHAVIOR
}

\author{
Milica Čolović, \\ Nikica Radović, \\ Angelina Njeguš \\ Singidunum University, \\ Belgrade, Serbia
}

\begin{abstract}
:
In the era of artificial intelligence, smart applications and robotization, that aim to recognize the user's profile, understand his needs and from the vast amount of data, create a personalized product/service, there is a need for a deeper understanding of the psychological factors of the users. Therefore, in this paper, the relations and impact of developmental crises, the sense of meaning in life and identity expansion, on cultural tourist behaviour, are discussed. Cultural tourism is a key contributor to the economy (81\%), social (51\%), cultural (46\%) and environment (16\%) and is considered to be the oldest type of tourism. In order to develop attractive cultural assets, cultural activities, cultural content or customised cultural tourism products/service, the understanding of cultural tourist types, motives and other factors are of key importance. One of the psychological aspects of cultural tourist behaviour, that was not considered enough in previous literature, is the midlife crisis. Taking into account how they cope with the midlife crisis, tourists can be divided into four groups: Denial of Escape, Denial by Overcompensation, Decompensation and Creative confrontation. During establishing a new balance in themselves, finding new sense of meaning in life and extending the boundaries of self and own identity, tourists strive to see authenticity in cultural experiences, search for real experiences, learn new things, become more conscious about preserving the nature, enjoy life and contribute to the others' life enjoyment. Besides these conclusions, this paper primarily aims at comprehending the influence of tourist's developmental crisis on his/her behavior and motives to consume cultural tourism products/services.
\end{abstract}

Keywords:

tourist behaviour, crisis, adolescence, mid-life, cultural tourism

\section{INTRODUCTION}

Tourism and traveling affect tourist's perceptions of themselves, family, friends, work and life in overall (Filep et al, 2017; Chen et al, 2016; Maoying and Pearce, 2014). The most researched field in marketing and tourism is consumer behavior. Tourist behavior is influenced by cultural, social and personal characteristics as well as tourist psychology (Kotler and Keller, 2009; Manrai and Manrai, 2011). Maoz (2006) claims that tourists behaviors are considerably affected by tourist's gender, status and nationality. Recent studies were concerned with several tourist psychology perspectives, such as
Correspondence: Angelina Njeguš 
motivation, values, personality, expectation, decision making, satisfaction, experience, trust, technology and relationship analysis (Cohen et al, 2013). These perspectives are directly involved in consuming of tourism products or services.

Understanding tourist motives is a key element in destination marketing and tourism product or service development. Although, in the era of artificial intelligence and robotisation, better understanding of psychological aspects of tourist, will help in customized destination offer. Development of chatbots, personal smart applications and robots in tourism industry, will require better understanding of deeper psychological factors of tourist. A number of prior studies investigated cognitive psychology in tourism that deal with human cognition i.e. mental abilities (e.g. perception, attention, memory, language processing, learning, understanding, problem solving) in order to understand the mental processes that influence tourist's perception and behavior (e.g. emotion reaction, intention to revisit). Skavronskaya et al. (2017) considered different human mental activities (e.g. consciousness, attention, memory, emotion) and their application to tourism, in order to understand how to promote tourism products or services, to persuade tourists, to enhance, shape and develop more mindful experiences and increase memorability.

Moutinho (1993) analyzed the influence of social psychology on individual travel behavior in order to develop a model of tourist behavior. Dimanche and Havitz (1995) considered the influence of ego, family, loyalty, and novelty-seeking, on tourism behavior. Manrai and Manrai (2011) developed a conceptual framework for analyzing tourist behavior where three categories of behavior were identified, such as: Social interaction driven behavior, Risk tendencies driven behavior and Collectivity orientation driven travel behavior. Christou et al. (2018) investigated the emotional dimension of tourist satisfaction at cultural events and proposed a conceptual model of the visitor satisfaction process. This model takes into account cognitive/affective visitor components, as well as endogenous/exogenous environmental dynamics that influence the route towards a satisfying visitor experience and its metacauses. In addition, Chetthamrongchai (2017) developed a destination image theoretical model that serves to destination marketing managers to develop a competitive position of the destination, by measuring tourists' motivation, information sources and perception of the destination crisis.

Tourism behavior involves different inter-correlated concepts, therefore in this paper developmental crises, sense of meaning in life and identity expansion were discussed in order to analyze their impact on cultural tourist behavior. The remaining parts of this paper are organized as follows: Introduction part reviews related research; the second part provides understanding of offered cultural tourism products and activities and analyze the types and motives of the cultural tourist. The third part provides a comprehensive study of the development crises, sense of the meaning of life, the identity expansion and their overall influence on cultural tourist behavior. Conclusion and future works are drawn in the final section of the paper.

\section{CULTURAL TOURISM AND TOURIST BEHAVIOR}

\section{Cultural tourism: types, products and activities}

Destinations has their own authenticity and attractiveness based on the tourist resources they have at their disposal. By covering natural and anthropogenic resources, as well as different types of accommodation and food facilities, various tourism products that are figuring in the tourist market are formed and serve to meet the needs of tourists in a particular destination. Tourism product can be defined as the mixture of different goods or services, that are offered as tourist experience (Gilbert, 1990). Depending on the needs and expectations of tourists, different types of tourist products and types of tourism are created: health tourism, business tourism, cultural tourism, educational tourism, sports tourism, mountain tourism, etc. These forms of tourism are the so-called alternative forms of tourism and are all more present in the choice of modern tourists compared to the classic mass-type of tourism "sun, sea, sand" (3S). According to the results of World Tourism Organization (UNWTO, 2018) survey on tourism and culture, $40 \%$ of international trips include cultural travelers who stay at the destination, because of their familiarity with the culture and tradition of that destination.

Cultural tourism is the oldest but still dominant form of travel, and that is because of tangible and intangible resources that exist in all countries and represent the potential tourist destinations, but also due to the impact 
on economic development or regeneration (Liu and Lin, 2011). The results of the EU project titled Cultural Heritage Counts for Europe (CHCfE) show that economic impact of the heritage is $81 \%$, social is $51 \%$, cultural is $46 \%$ and environmental impact is $16 \%$, that makes cultural tourism a key contributor to the Europe 2020 . Some key findings of the project summaries that cultural tourism contributes to the (CHCfE, 2015): (1) attractiveness of Europe's destinations; (2) identity to the European countries and regions; (3) employment; (4) creativity and innovation, (e.g. digitization, protection and revitalization of cultural assets); (5) the quality of life, making cities and regions popular places to live, work and visit; (6) education and lifelong learning (foster cooperation and personal development and feeling of civic pride and belonging); (7) social cohesion, foster participation, engagement and integration of European communities.

Since cultural tourism is directed towards experiencing local arts, heritage, landscapes, tradition and lifestyles, the common cultural tourism activities are (Cros and McKercher, 2015; Csapo, 2012): Heritage (nature, ecotourism, architectural sites, historical memorials, monuments, folklore, art, theatres, libraries, museums, events); Cultural thematic routes (architectural, artistic, industrial, spiritual, gastronomic, linguistic, botanical gardens, wildlife, regional routes, thematic itineraries, leisure and service industry); Cultural tours (sightseeing, city tour, villages tour); Ethnic tourism (traditions, ethnic diversity); Event tourism (music, dance, fine arts); Religious tourism (pilgrimage, religious sites); Creative tourism (performing arts, visual arts, printed works, multimedia, craft, design). Essential motivation of cultural tourist is to discover, experience, learn and consume cultural products, that are based on the lifestyle and value systems of a particular area (UNWTO, 2018).

In order to attract cultural tourists, countries seek to develop new creative strategies, build new cultural resources, conserve traditional cultures and to create a cultural image. However, today cultural tourism is under increasing pressure from globalization, standardization and internationalization (Carson and Pennings, 2017), therefore the new ways to attract cultural tourist has to be found.

\section{Cultural tourist: types and motives}

It is often difficult to distinguish cultural tourists' motives, from others, because of the tendency to combine different motives for holiday. However, McKercher and Hilary (2002) defined five types of cultural tourists: (a) Purposeful (has a very deep previous cultural experience); (b) Sightseeing (ends up with a less deep experience); (c) Serendipitous (accidental) (does not travel for cultural reasons, but after experiencing it, ends up with deep cultural tourism experience); (d) Casual (weak motive for cultural tourism and the resulting experience is superficial); (e) Incidental (does not travel for cultural motives, but participates in some activities).

According to Hughes and Allen (2005), cultural tourist are well educated, affluent, expect different experiences and broadly travelled. During their experiences, they usually interact with physical (e.g. built heritage), general (e.g. daily life of the host community) and specific cultural attributes (e.g. festivals) (Gunlu et al, 2009). The amount of cultural tourists and their expenditures, in 2011, were 180.000 night visits, 775.000 day trips and 55 million euro of income (CHCfE, 2015). According to Bausch (2016), senior tourists (65+) make longer trips, usually in their country of residence and stay at non-rented accommodation. The overall tourist motive factors (Pearce, 2005), are: (1) Personal self-development (2) Nature (3) Nostalgia (4) Self-actualization (5) Stimulation to explore unknown (e.g. feeling excitement, experiencing thrills, having adventure) (6) Secure relationship (7) Strengthen relationship (8) Recognition (9) Autonomy (e.g. being independent) (10) Selfimprovement (11) Escape/Relax (12) Isolation (13) Romance (14) Novelty (e.g. experiencing something new).

\section{THE INFLUENCE OF DEVELOPMENT CRISES, SENSE OF MEANING IN LIFEAND IDENTITY EXPANSION ON CULTURAL TOURIST BEHAVIOR}

\section{The meaning of development crises}

Developmental crises are periods in the life of a person when it comes to transformation and building a new identity, sense of the meaning of life and finding own role in the new circumstances. They occur in the transient stages of life, that is, they are instigated by the very process of development (Pavlović, 2014). The two 
major developmental crises in human life are adolescence and mid-life crises. During adolescence, for the first time, the experience of one's own identity, its particularities, is clearly being built up for the first time, through the testing of own boundaries and for the first time testing in the play different life roles - a young woman or a man. The period of childhood is abandoned and the mature age has not yet begun, thus the person is broken and at the border between a child and an adult.

Another major crisis occurs during the transition from adulthood to old age, so called midlife crisis. Midlife crisis is a transition process of the self where the reinterpretation of time perspective, re-evaluation of life values and goals, confrontation with death and planning of the second half of life, were reconsidered (Hermans and Oles, 1999). About the age of 40, when the feeling of own identity is finally stable and the sense of the meaning of life is built, the person comes to a new turning point in life, where it becomes necessary to face with own final and death. Fear of death becomes dominant and it actually triggers deep internal changes that are very painful for a person, that must surely be played in order to keep the person continue to develop and grow (Levinson, 1978; Levinson and Fooden, 1985). It can be expressed very obviously, but more often it comes masked through various manifestations that are characteristic for the mid-life crisis (Marmor, 1974; Pavlović, 2014). Awareness that a person has passed half of life leads to a serious review of own identity and a kind of „reckoning" with self (Pavlović, 2011; Pavlović 2014). It is a period that begins in the fifth decade of human life and lasts for a very long time. According to the latest research, certain internal changes are ending between the 75th and the 80th years of person's life, although they begin much earlier (Pavlović, 2011; Čolović, 2017; Čolović and Stojković, 2017). Studies on tourist in transitional phases reported that prior to traveling, tourist has experienced some sort of life crisis (Maoz, 2006). According to form of transformation, Smith (2013) suggests possible routes to transformation (Table 1).

Table 1. Possible routes according to tourist's form of transformation (Smith, 2013)

\begin{tabular}{lll}
\hline $\begin{array}{c}\text { Transformation } \\
\text { form }\end{array}$ & \multicolumn{1}{c}{ States } & \multicolumn{1}{c}{ Routes } \\
\hline Physical & $\begin{array}{l}\text { Taking care of the health and body; changing } \\
\text { lifestyle; slowing down the life }\end{array}$ & $\begin{array}{l}\text { Nutrition, fitness, massage, complementary ther- } \\
\text { apies, medical treatments. }\end{array}$ \\
\hline Psychological & $\begin{array}{l}\text { Facing life's challenges with courage; living the } \\
\text { present moment; learning to think positively and } \\
\text { be life affirming. }\end{array}$ & $\begin{array}{l}\text { Mindfulness, meditation, yoga, visualizations, } \\
\text { affirmations, mantras, life-coaching. }\end{array}$ \\
\hline Existential & $\begin{array}{l}\text { Being true on oneself, discovering the essence } \\
\text { of self, being existentially authentic; creating the } \\
\text { meaning in the face of anxiety; practicing being } \\
\text { my-self. }\end{array}$ & $\begin{array}{l}\text { Holistic workshops, pilgrimage, travelling alone, } \\
\text { seeking new and unique experiences, not follow- } \\
\text { ing the crowd, social networks of like-minded } \\
\text { people, spiritual activities (yoga, meditation etc.) }\end{array}$ \\
\hline Spiritual & $\begin{array}{l}\text { Practicing anti-materialism; experiencing joy; } \\
\text { facing challenges with equanimity. }\end{array}$ & $\begin{array}{l}\text { Dancing, singing, celebrating, being creative, } \\
\text { Buddhist philosophy. }\end{array}$ \\
\hline Social & $\begin{array}{l}\text { Socially responsible for well-being of others and } \\
\text { one's own; contributing rebuilding communities. }\end{array}$ & $\begin{array}{l}\text { Charity, teaching, conservation, construction. } \\
\text { Cultural }\end{array}$ \\
\hline Practicing tolerance, cross-cultural exchange & $\begin{array}{l}\text { Attending cultural events, visiting different com- } \\
\text { munities. }\end{array}$ \\
\hline Environmental & $\begin{array}{l}\text { Appreciating the nature; outdoor recreation } \\
\text { Spending more time in natural landscapes and } \\
\text { green spaces, protecting nature, hiking, trekking, } \\
\text { climbing, rafting, swimming. }\end{array}$ \\
\hline
\end{tabular}

\section{The Sense of meaning in life}

Any stage of life crisis opens or reconsiders the existential question - the meaning of life. In searching for an authentic self, adolescents start to explore the sources of meaning in life (Brassai et al, 2012). Middle-aged people are in constant discovering of new aspects of meaning in life. That search begins to grow more intense somewhere between the ages of 45 and 49, and culminates in the period between 60 and 64 years of age, after 
that starts to decrease in intensity. It is usually not clear to people whether they have found an adequate and satisfactory sense of life, therefore they are in a constant search for its discovery (Pavlović, 2014; Čolović, 2017; Čolović and Stojković, 2017).

Marmor (1974) argued that people have four different ways in which they can resolve the mid-life crisis. They can try to deny it by trying to put too much business or hobby-related obligations to themselves, so that they could not have enough time to deal with their own mortality, which is explained by the term "Denial by escape". Another way is not accepting changes in physical and psychological functioning, through emphasizing that current period of life is the best for them, that they have never felt healthier, younger and more agile. This may result in the potentiation youthful style and way of life, that include night outings, youthful dress, different rejuvenation procedures, the accumulation of material things (e.g. fast car) and attempts to change life from the root, through frequent partners change, or start a completely new life by abandoning the family and creating a new one, which Marmor referred to as "Denial by overcompensation". On the other hand, people can accept the transition from the middle to the late years as inevitability and this can cause either depression, big fall in instinctive-voluntary dynamics, apathy, which Marmor has conquered with the term "Decompensation". Finally, they can "Creatively and successfully confront the mid-life crisis", which presents the best way of overcoming, in which person finds new sources of pleasure in spite of the awareness of the process of aging and confrontation with death, through extending their own boundaries and sights, returns to some of the long-lost hobbies and activities that made them happy and reveals the new sense of meaning in life.

\section{Identity expansion and influence on cultural tourist behavior}

Identity is a combination of internal psychological development (characterized by traits, goals, abilities, values) and social processes (Oyserman et al, 2012). Adolescence is seen as the process of rebalancing old with new, i.e. transformation from the childhood ideological views with own perception of life caused by cognitive abilities and social awareness. Development of identity is correlated with development of meaning of life (Brassai et al, 2012).

Recent studies show that denial by overcompensation is intense in the period between 25 and 30 years of age, and decompensation and denial by escape occur most intensely between the ages of 50 and 54 (Pavlović, 2014; Colović 2017). This could indicate that in middle age people, especially between 60 and 64 when they particularly seek to find a new sense of meaning in life and when they extend the boundaries of the experience of their own self and identity, the dominant starting point is "cultural tourist", in contrast to the "post-tourist" which may have been more appropriate for the period of adolescence (Pavlović, 2011; 2014). In the middleaged, there are massive changes in internal functioning, reflected in establishment of a new balance and the suppression of certain contradictions that once were very pronounced - young-old, masculinity-femininity, approach-separation, win-loss (Levinson, 1978; Levinson and Fooden, 1985; Pavlović, 2011; Čolović, 2017, Čolović and Stojković, 2017). The people try to establish a new balance in themselves, which will enable them to expand their borders and enjoy life more, which in terms of tourism can be seen as they accept and received more "living" concepts of tourism (Smith, 2003). The person who is facing the middle-aged crisis in the best way and optimally overcomes it, finding new sense of meaning in life and extending the boundaries of self and own identity, strives to see, experience, enjoy life, preserve the nature, buy and learn things.

\section{CONCLUSION}

This study was an initial attempt to understand the influence of developmental crises, sense of meaning in life, identity expansion on cultural tourist behavior. The findings of this research provide a comprehensive view of the influence of psychological factors on cultural tourist behavior. According to demographic trends, the prolonged lifespan is one of the main trends and parameters in the monitored trends in the tourism market and the issue of healthy state and preservation are of particular importance. Therefore, in order to adapt to latest trends, tourism sector must take into account the wishes of different demographic groups and accordingly develop tourism products. The advantage of cultural tourism as a tourist segment is in a kind of universality, 
bearing in mind the wide range of products that this type of tourism offers on the tourist market. Creative tourism is related to an engaged and authentic tourist' experience, which fully fits into the mechanism of creative and successful coping with the mid-life crisis.

\section{REFERENCES}

Baushc, A.M. (2014). Tourism trends and ageing. Eurostat - Statistics Explained. Available online: https://ec. europa.eu/eurostat/statistics-explained/index.php/Tourism_trends_and_ageing (Accessed: 4.9.2018)

Brassai, L., Piko, B.F., \& Steger, M.F. (2012). Existential Attitudes and Eastern European Adolescents' Problem and Health Behaviors: Highlighting the Role of the Search for Meaning in Life. The Psychological Record, 62(4), 719-734. DOI:10.1007/BF03395831

Carson, S., \& Pennings, M. (2017). Performing Cultural Tourism: Communities, Tourists and Creative Practices. Routledge, Taylor \& Francis Group.

CHCFE (2015). Cultural Heritage Counts for Europe Report, CHCfE Consortioum, International Cultural Centre, Krakow. Available online: http://www.europanostra.org/our-work/policy/cultural-heritage-countseurope/ (Accessed: 4.9.2018).

Chen, C-C., Huang, W-J., \& Petric, J.F. (2016). Holiday recovery experiences, tourism satisfaction and life satisfaction - Is there a relationship? Tourism Management, Vol. 53, 140-147. DOI:10.1016/j.tourman. 2015.09.016

Chetthamrongchai, P. (2017). The Influence of Travel Motivation, Information Sources and Tourism Crisis on Tourists' Destination Image. Journal of Tourism and Hospitality, 6(2), 1-6.

Christou, P., Sharpley, R., \& Farmaki, A. (2018). Exploring the emotional dimension of visitors' satisfaction at cultural events. Event Management, 22(2), 255-269. DOI:10.3727/152599518X15173355843389

Cohen, S.A., Prayag, G., \& Moital, M. (2014). Consumer behavior in tourism: Concepts, influences and opportunities. Current Issues in Tourism, 17(10), 872-909. DOI:10.1080\%2F13683500.2013.850064

Filep, S., Laing, J., \& Csikszentmihalyi, M. (2017). Positive Tourism. Taylor \& Francis Group, Routledge.

Čolović, M. (2017). Kriza srednjih godina u savremenoj Srbiji, Glasnik antropološkog društva Srbije, pp. 1-8.

Čolović, M., \& Stojković, M. (2017). Kriza srednjih godina - spoljašnje manifestacije i unutrašnje promene (prihvaćen), Teme, pp. 1-21.

Cros, H., \& McKercher, B. (2015). Cultural Tourism, second edition. Routledge, Taylor \& Francis Group.

Csapó, J. (2012). The Role and Importance of Cultural Tourism in Modern Tourism Industry. Strategies for Tourism Industry- Micro and Macro Perspectives. DOI:10.5772/38693.

Dimanche, F., \& Havitz, M. E. (1995). Consumer behavior and tourism. Journal of Travel \& Tourism Marketing, 3(3), 37-57.

Gilbert, D. (1990). Strategic marketing planning for national tourism. The Tourist Review, 45(1), 18-27.

Gunlu, E., Pirnar, I., \& Yagsi, K. (2009). Preserving Cultural Heritage and Possible Impacts on Regional Development: Case of Izmir. International Journal of Emerging and Transition Economies, 2(2), 213-229.

Hermans, H.J.M., \& Oles, P.K. (1999). Midlife Crisis in Men: Affective Organization of Personal Meanings. Human Relations, 52(11), 1403-1423.

Hughes, H., \& Allen, D. (2005) Cultural Tourism in Central and eastern Europe: The views of 'induced image formation agents'. Tourism Management, 26(2), 173-183.

Kotler, P., \& Keller, K. L. (2009). Marketing Management (13th Ed.). Upper Saddle River, NJ: Prentice Hall.

Levinson, D. (1978). The seasons of man's life. New York: Alfred A. Knopf.

Levinson, D., \& Fooden, W. (1985). The life cycle, In: Kaplan, H., Sadok, B.: Comprehensive Textbook of Psychiatry, London: Williams Wilkins, 1-41.

Liu, Y-D., \& Lin, C-F. (2011). The Development of Cultural Tourism: A Review of UK Experience. Tourismos: An international Multidisciplinary Journal o Tourism, 6(2), 363-376.

Manrai, L. A., \& Manrai, A. K. (2011). Current Issues in the Cross-cultural and Cross-national Consumer Research in the Global Economy of the Twentyfirst Century. Journal of International Consumer Marketing, 23(3/4), 167-180.

Maoz, D. (2006). Erikson on the Tour. Tourism Recreation Research, 31(3), 55-63.

Maoying, W., \& Pearce, P.L. (2014). Positive psychology and its applications in Tourism Studies. Tourism Tribune, 29(1), 39-46. 
Marmor, J. (1974). The crisis of middle age, In: J. Marmor (eds.), Psychiatry in Transition (71-76), New York: Brunner Mazel Inc.

McKercher, B., \& Hilary, C. (2002). Cultural Tourism: The Partnership Between Tourism and Cultural Heritage Management. New York: Hayworth Hospitality Press.

Moutinho, L. (1993). Consumer behaviour in tourism. European Journal of Marketing, 21(10), 5-44.

OECD (2018) Megatrends shaping the future of tourism. OECD Tourism Trends and Policies 2018. Part I, Chap ter 2. Available at: https://www.oecd-ilibrary.org/docserver/tour-2018-6 en.pdf?expires=1536099183\& $\mathrm{id}=\mathrm{id} \&$ accname $=$ guest\&checksum=28B8C8FCEE0DEAB647C2BB9B11A0CBA7 (accessed: 5.09.2018).

Oyserman, D., Elmore, K., Smith, G. (2012) Self, Self-Concept, and Identity. Chapter 4 in Handbook of Self and Identitiy, second edition. Edited by Leary, M.R. and Tangney, J.P. The Guilford Press, pp. 69-104.

Pavlović, M. (2011). Promene u doživljaju identiteta i razvoj generativnosti kod osoba u srednjim godinama, Godišnjak za psihologiju, 8(10), 41-53.

Pavlović, M. (2014). Načini ispoljavanja krize srednjih godina, osećanje smisla života i oblici usklađivanja porodičnih i profesionalnih uloga u Srbiji, doktorska disertacija, Filozofski fakultet Univerziteta u Nišu, $1-446$.

Pearce, P.L. (2005). Tourist Behaviour: Themes and Conceptual Schemes. Clevedon: Channel View Publications.

Skavronskaya, L., Scott, N., Moyle, B., Le, D., Hadinejad, A., Zhang, R., Gardiner, S., Coghlan, A., \& Shakeela, A. (2017) Cognitive psychology and tourism research: state of the art. Tourism Review, 72(2), 221-237.

Smith, M. K. (2003). Issues in Cultural Tourism Studies. London and New York: Routledge

Smith, M. (2013). Transforming quality of life through wellness tourism. In: Transformational Tourism: tourist Perspectives, Ed. by Reisinger, Y. CAB International 2013, pp. 55-67.

UNWTO (2018). Tourism and Culture Synergies. Available at: https://www.e-unwto.org/doi/pdf/10.18111/ 9789284418978 (accessed 5.9.2018). 